\title{
Examining Peer Presure on Children
}

\author{
Magdalene Peter, S.Fabiyola Kavitha, K.Anitha Davamani
}

\begin{abstract}
Friend weight (or social weight) is the immediate impact on individuals by companions, or the impact on a person who gets urged to pursue their friends by changing their mentalities, qualities or practices to adjust to those of the affecting gathering or person. This can bring about either a positive or negative impact. Social gatherings influenced incorporate both participation gatherings, in which people are "officially" individuals, (for example, ideological groups and worker's guilds), and inner circles, in which enrollment isn't plainly characterized. In any case, an individual shouldn't be a part or be looking for participation of a gathering to be influenced by companion weight. [1],[3],[5]
\end{abstract}

\section{Keywords : children, peer pressure, adolescents}

\section{INTRODUCTION}

There has been impressive examination with respect to companion weight's impacts on kids and youths, and in well known talk the term is for the most part utilized with regards to those age gatherings. For youngsters, the regular topics for study respect their capacities for autonomous basic leadership; for teenagers, peer weight's association with sex and substance misuse have been essentially inquired about. Companion weight can influence people all things considered, sexual orientations and ages, be that as it may. Companion weight has moved from carefully up close and personal cooperation to advanced collaboration too. Online networking offers open doors for young people and grown-ups alike to ingrain or potentially experience weight ordinary. Research recommends that people as well as associations, for example, huge companies, are powerless to friend weights, for example, weights from different firms in their industry or central command city. [2 ],[ 4],[6]

\section{A. Children}

Pantomime assume a gigantic hobby in children' lives; for you to get aptitudes and frameworks that they use in their own one in all a type life, children are continuously searching for practices and attitudes round them that they could co-pick. kids think about their condition in the social motion considering that at an opportune time: their temperament is to surrender to adults' selections and principal component estimations. just like the Asch congruity breaks down, an assessment executed on social events of preschool kids exhibited that they have been motivated through

Revised Manuscript Received on July 22, 2019.

Magdalene Peter, Department of MBA, Bharath Institute of Higher Education and Research, Tamilnadu, India. Email: magdalene.bsb@gmail.com

Dr.S.Fabiyola Kavitha, Department of MBA, Bharath Institute of Higher Education and Research, Tamilnadu, India. Email: fabiyolakavitha@gmail.com

K.Anita Davamani, Department of CSE, Bharath Institute of Higher Education and Research, Tamilnadu, India. Email: anitadavamani@gmail.com get-togethers in their companions to alternate their appraisal to an authentically off kilter one.every baby turned into given a e-book with game plans of pictures on every web page, with a get-togethers of particularly estimated animals on the left hand web page and one animal on the proper hand, and each tyke became asked to demonstrate the dimensions from the single animal. all of the books confirmed up the identical, yet the last toddler could to a notable extent get a book that became awesome. [25],[27],[29]The youth uncovered their size alternatives along those traces, and the kid being attempted changed into asked ultimate. before the character being noted, though, had been a social occasion of youngsters running diagnosed with the researchers. every so often, the youngsters who spoke back earlier than the guinea pig all presented a reaction that changed into incorrect. precisely while asked in the proximity from various youths, the last tyke's reaction became frequently same to his or her partners. however, while allowed to subtly bestow their responses to an expert the youngsters showed altogether increasingly impenetrable to their partners' weight, speakme to the hugeness of the bodily closeness in their colleagues in framing their critiques[7],[9],[11]

\section{OBJECTIVES}

- Investigate the effect of family, peers, culture, media, advancement, and various factors on prosperity rehearses

- Demonstrate the ability to use essential authority aptitudes to improve prosperity and target setting

- Students will contemplate weight from companions and their home situation

- Students will make sense of how to recognize frameworks to adjust to buddy weight and understand what's basic to their future accomplishment.

- Students will confer through created and visual language to express

\section{RESEARCH MATHODOLOGY}

A studying is that children can display screen and intrude of their buddies' direct via weight. An evaluation drove in a mending kindergarten magnificence inside the Edna A. Slant baby development [31],[33],[32]Laboratory inside the university of Kansas prepared a program to evaluate how children ought to ease problematic lead of their companions thru a -area structure. in the wake of delineating a motion of assignments to their investigation hall that protected rest room use, cleansing up, and general homeroom lead, teachers and examiners could watch children's display at the duties. 
The assessment centered on three youngsters who had been in reality perceived as being more unsafe than their associates, and seemed responses to ability frameworks. The shape applied changed into a two-section one: first, every understudy might be given concentrations by their instructors for precisely completing responsibilities with little aggravation (as an example plunking down on a tangle for scrutinizing time), and if an understudy touched base at three preceding the day's over they could get a prize. The resulting part received companion cooperation, [26],[28],[30]wherein understudies who landed at three factors were selected "peer screens" whose interest turned into to lead their little get-togethers and dispense centers constantly cease. The consequences have been self-obvious, displaying that the checked understudies' unsettling impact dropped when educators commenced the facilities device and watched them, but when pal displays had been introduced the purpose understudies' intrusion dropped to average paces of $1 \%$ for understudy $\mathrm{C} 1,8 \%$ for understudy $\mathrm{C} 2$, and $11 \%$ for understudy C3 (down from 36\%, sixty two\%, and fifty nine $\%$, independently). For certain, even little children, via then, are liable to weight from their allies, and that weight can be used to affect tremendous alternate in instructional and social circumstances. [8],[ 10], ,12]

\section{RESULTS AND DISCUSSION}

A large portion of the understudies (63.5\%) supposedly felt focused on due to scholastic weight .training level of the dad was essentially connected with scholarly weight $(\chi 2(1$, $\mathrm{N}=159)=5.96, \mathrm{p}=.015)$ : members whose fathers were non-graduates were observed to be bound to report scholastic weight. There were no noteworthy contrasts in scholastic worry crosswise over sexual orientation, age, class, and different components. [13], [15] ,[ 17]

Scholarly pressure was decidedly corresponded with parental weight $(\chi 2(1, \quad \mathrm{~N}=187)=11.89, \quad \mathrm{p}=.001)$ however not assessment tension $(\chi 2(1, \mathrm{~N}=189)=1.99, \mathrm{p}=.158)$. There was no huge connection between parental weight and assessment related nervousness. [14],[ 16], [18]

A few strategic relapses were directed to analyze the connections between scholarly pressure, parental weight, assessment related uneasiness and mental caseness. Results demonstrated that scholastic pressure $(\mathrm{OR}=2.3,95 \% \mathrm{CI}: 1.2$ $-4.6)$ and assessment tension (OR=2.7, 95\% CI: $1.1-7.0)$ were altogether connected with mental caseness. At the point when the effect of sexual orientation was controlled, the connection between scholastic pressure and emotional wellness stayed huge (Adjusted OR $=2.2,95 \%$ CI: 1.1 4.4). Parental weight likewise had a positive yet not measurably noteworthy relationship with mental caseness. [19],[21],[23]

\section{CONCLUSION}

Pantomime anticipate a enormous hobby in children's lives; to get aptitudes and frameworks that they use of their very very own existence, youngsters are always examining for practices and outlooks round them that they are able to co-choose. youngsters think about their condition within the social hierarchy of leadership due to the fact from the get-go: their tendency is to yield to adults' choices and bigger element ends. alongside those strains they ought to Understandthe impact of sidekick weight. [20],[22], [24]

\section{REFERENCES}

1. G BharthVajan R., Ramachandran S.,Psychographic dimensions of training,2016,International Journal of Pharmacy and Technology,V-8,I-4,P-23727-23729

2. Balakrishnan P., Bharthvajan R.,A study on human resource planning in hospitals in Chennai City,2014,International Journal of Applied Engineering Research,V-9,I-22,P-7503-7507

3. Priyadarsini P., Bharthvajan R.,Role of emotional intelligence training programme in reducing the stress of the nurses,2014,International Journal of Applied Engineering Research, V-9,I-22,P-7411-7421

4. Kerinab Beenu G., Bharthvajan R.,Empirical analysis on the cosmetic buying behavior of young women in South India,2014,International Journal of Applied Engineering Research,V-9,I-22,P-7361-7366

5. Balakrishnan P., Bharthvajan R.,Whistling in the wind,2014,International Journal of Applied Engineering Research,V-9,I-22,P-7586-7593

6. Krishnan B., Peter M.,Health hazards of Indian Bpo employee-an alarming issue,2014,International Journal of Applied Engineering Research,V-9,I-22,P-7336-7341

7. Kerinab Beenu G.H., Peter M.,Role of insurance in economic development,2014,International Journal of Applied Engineering Research,V-9,I-22,P-7532-7539

8. Balakrishnan P., Peter M., Priyadarsini P.,Efficiency of safety measures for wellbeing of employees in manufacturing industry,2014,International Journal of Applied Engineering Research,V-9,I-22,P-7376-7382

9. Anbarasi M., Praveen Kumar S.,Online sales promotions of herbal products and its effectiveness towards tanisha.com,2019,Indian Journal of Public Health Research and Development,V-10,I-1,P-195-200

10. Anbarasi M., Praveen Kumar S.,Various online marketing and promotions strategies to improve the validation towards the organic products in the pharmaceutical sectors,2019,Indian Journal of Public Health Research and Development,V-10,I-1,P-263-269

11. Loganathan R., Praveen Kumar S.,Grievance handling a key factor for solving issues of employees in an organization,2014,International Journal of Applied Engineering Research,V-9,I-22,P-7483-7491

12. Loganathan R., Praveen Kumar S.,Study on preference of private label brands in super and Hypermarkets,2014,International Journal of Applied Engineering Research,V-9,I-22,P-7327-7335

13. Smitha M., Praveen Kumar S.,Understanding stress and its managementamong the nurses in Chennai city,2014,International Journal of Applied Engineering Research,V-9,I-22,P-7560-7565

14. Kerinab Beenu G.H., Praveen Kumar S.,A study on the investment behavior of Chennai investors in mutual fund schemes,2014,International Journal of Applied Engineering Research,V-9,I-22,P-7520-7525

15. Loganathan R., Praveen Kumar S.,Retention strategies key for organizational productivity,2014,International Journal of Applied Engineering Research,V-9,I-22,P-7443-7447

16. Pavithra J., Ganesan M., Brindha G.,State wise analysis of microfinance sector in India,2016,International Journal of Pharmacy and Technology,V-8,I-4,P-23417-23432

17. Pavithra J., Ganesan M.,A comparative study on microfinance in India and abroad,2016,International Journal of Applied Business and Economic Research,V-14,I-8,P-5471-5476

18. Pavithra J., Ganesan M.,A study on awareness and impact of micro-financial schemes,2016,International Journal of Applied Business and Economic Research,V-14,I-8,P-5449-5460

19. Senthilmurugan P., Pavithra J.,Consumer preference towards organised retailing with reference to Big Bazaar,2014,International Journal of Applied Engineering Research,V-9,I-22,P-7469-7475

20. Senthilmurugan P., Pavithra J.,Implication of social media marketing in growing healthcare industry,2014,International Journal of Applied Engineering Research,V-9,I-22,P-7448-7456

21. Loganathan R., Pavithra J.,Consumer perception towards private label brand over other brands in super markets and hypermarkets,2014,International Journal of Applied Engineering Research,V-9,I-22,P-7355-7360 
22. Kerinab Beenu G., Pavithra J.,Tradeâ€"off between liquidity and profitability in logistics industry,2014,International Journal of Applied Engineering Research,V-9,I-22,P-7398-7401

23. Kerinab Beenu G., Pavithra J.,A study on the prospective consumerâ€ TM $_{\mathrm{S}}$ perception towards utility cars in Chennai city,2014,International Journal of Applied Engineering Research,V-9,I-22,P-7526-7531

24. Pavithra J., Dilli Babu P., Ambuli T.V.,A study on budgetary control at Maruti Service Masters, Chennai,2014,International Journal of Applied Business and Economic Research,V-12,I-2,P-151-161

25. Pavithra J., Dilli Babu P., Ambuli T.V.,A study on customer satisfaction of retro Garments Pvt Ltd, Chennai,2014,International Journal of Applied Business and Economic Research,V-12,I-2,P-381-391

26. Kerinab Beenu G.H., Pavithra J., Senthilmurugan P.,A study on the influence of promotional activities for TATA ARIA among consumers in Chennai,2014,International Journal of Applied Engineering Research,V-9,I-22,P-7572-7578

27. Vijayaragavan S.P.,An investigative expert that's general FBG sensors,International Journal of Mechanical Engineering and Technology,V-8,I-8,PP-1500-1505,Y-2017

28. Vijayaragavan S.P.,Equalization routing protocol for Wi-Fi sensor strategy,International Journal of Mechanical Engineering and Technology,V-8,I-8,PP-1662-1666,Y-2017

29. Karthik B., Kiran Kumar T.V.U., Vijayaragavan P., Bharath Kumaran E.,Design of a digital PLL using 0.35 $\hat{\mathrm{I}}^{1 / 4 \mathrm{~m}}$ CMOS technology,Middle East Journal of Scientific Research,V-18,I-12,PP-1803-1806,Y-2013

30. Kanniga E., Selvaramarathnam K., Sundararajan M.,Kandigital bike operating system,Middle - East Journal of Scientific Research,V

31. Jasmin M., Vigneshwaran T., Beulah Hemalatha S.,Design of power aware on chip embedded memory based FSM encoding in FPGA,International Journal of Applied Engineering Research,V-10,I-2,PP-4487-4496,Y-2015

32. Jasmin M.,Optimization techniques for low power VLSI circuits,Middle East Journal of Scientific Research,V-20,I-9,PP-1082-1087,Y-2014

33. Jasmin M., Vigneswaran T.,Fuzzy controller for error control of on - Chip communication,2017 International Conference on Algorithms, Methodology, Models and Applications in Emerging Technologies, ICAMMAET 2017,V-2017-January,I-,PP-1-5,Y-2017

\section{AUTHORS PROFILE}

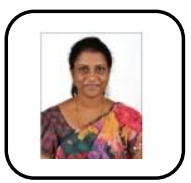

Magdalene Peter, Assistant Professor ,Department of MBA, Bharath Institute of Higher Education and Research, Tamilnadu, India

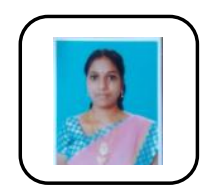

Fabiyola Kavitha ,Associate Professor ,Department of MBA, Bharath Institute of Higher Education and Research, Tamilnadu, India

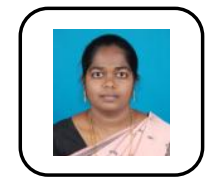

Anita Davamani, Assistant Professor ,Department of CSE, Bharath Institute of Higher Education and Research, Tamilnadu, India 